Editorial

\title{
Micro: An International Open Access Journal for All of Microscale and Nanoscale Science
}

\author{
Eiichi Tamiya
}

check for updates

Citation: Tamiya, E. Micro: An International Open Access Journal for All of Microscale and Nanoscale

Science. Micro 2021, 1, 1-2.

https://doi.org/10.3390/

micro1010001

Received: 31 March 2021

Accepted: 31 March 2021

Published: 6 April 2021

Publisher's Note: MDPI stays neutral with regard to jurisdictional claims in published maps and institutional affiliations.

Copyright: (C) 2021 by the author. Licensee MDPI, Basel, Switzerland. This article is an open access article distributed under the terms and conditions of the Creative Commons Attribution (CC BY) license (https:// creativecommons.org/licenses/by/ $4.0 /)$.
Advanced Photonics and Biosensing Open Innovation Laboratory, National Institute of Advanced Industrial Science and Technology (AIST), Osaka 565-0871, Japan; tamiya@ap.eng.osaka-u.ac.jp

Since the late 20th century, there has been a special interest in the microscale and nanoscale research investigating and exploiting the physical, chemical, and biological properties of these length-scale systems. Microscale and nanoscale science and technology are basically science and engineering carried out on the micrometer, $10^{-6} \mathrm{~m}$ scale, and nanometer, $10^{-9} \mathrm{~m}$ scale, respectively.

Significantly different from the properties of the macroscale or conventional scale, various interesting and novel phenomena have been observed and discovered over recent decades that led to opportunities for the creation of new materials with superior biological, chemical, and/or physical properties, as well as the development of new technologies. Research on microscale science allowed scientists to map cells, understand cell organization and gene patterns. With rapid advancement in micromachining, it enabled miniaturization of devices, fabrication of Lab-on-a-chip (LoC) or micro total analysis systems ( $\mu$ TAS) that are more efficient than conventional approaches. Manipulation of matter at single-level atoms or molecules to characterize material properties and systems has become possible in nanoscale research. These advancements have led to amazing discoveries and various applications that are seen in various products and industries that impact our daily lives. Due to its broad scope and interest in the field, a journal dedicated to microscale and nanoscale science is needed (Figure 1).
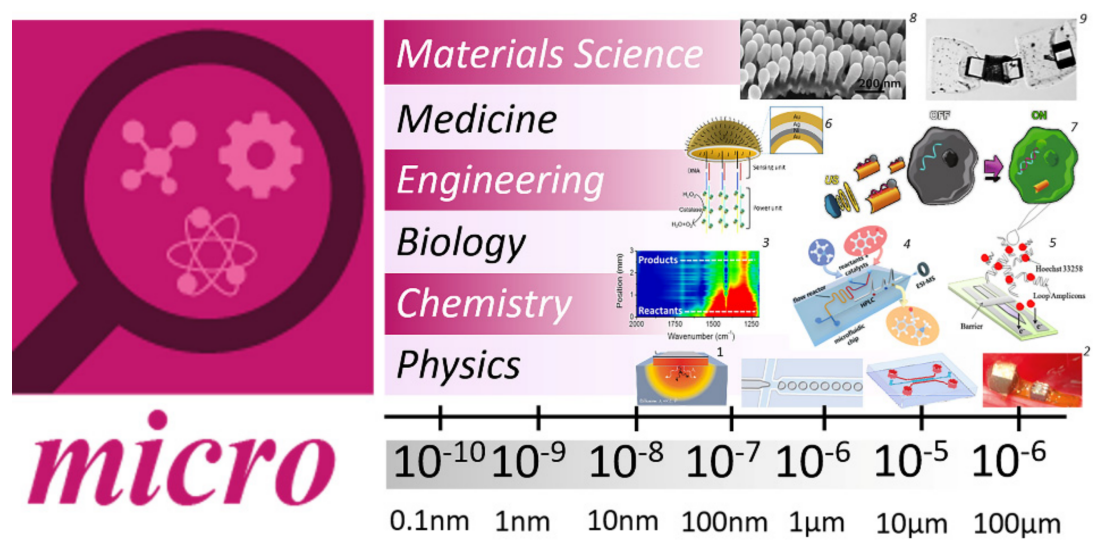

Figure 1. Scope of Micro journal [1-9].

Micro (ISSN 2673-8023) is an international, open access, and peer-reviewed scholarly journal of scientific studies related to all aspects of microscale and nanoscale researche, such as chemistry, physics, biology, biochemistry, medicine, engineering, nanotechnology, biotechnology, optics, material science, and electronic science. It publishes comprehensive reviews, original scientific research articles, communications, case reports, letters, commentaries, and editorials. Micro covers full experimental and theoretical results, and progress in the multidisciplinary aspects and applications related to this field. Our aim is to 
encourage scientists to publish their experimental and theoretical research in as much detail as possible. Micro includes studies related to microanalysis, microreactors, microstructure, microscale peptide chromatography, and microscale separations; microfluidics, microscale heat transfer, and microscale electronic science; micromachinery, microscanners, microand nano-motors, and microbiorobotics; immunofluorescence, microenvironments, NMR, microscope imaging, microscale biotechnology, analysis, biosensing and bioprocessing systems; cell-based microscale technologies, microscale drug delivery systems, medical devices, and thermophoresis; nanotechnology, microscale hydrogels, microstructural degradation, and microscale filler; microscale models, and microscopy.

With the broad range of applications, the significance of a comprehensive journal covering all microscale and nanoscale science is evident. This journal aims to deliver scientific information to the members of this research community by being a central repository of high quality, peer-reviewed articles. We welcome all relevant, high quality, scientific papers on microscale and nanoscale science.

The Editorial Board is composed of experts in the field of microscale materials science, engineering, biology and medicine, and physics, which reflects the varied interests of the research community it represents. Our group of experienced editors work together to ensure the quality of contributions that are scientifically valid and suitable for Micro. Thus, this journal's success depends on the high-quality articles and reviews that you and your colleagues submit. Together with the members of the Editorial Board, I look forward to your contributions.

Acknowledgments: The author would like to thank Jonathan C. Briones and Wilfred V. Espulgar for their supports on this editorial.

Conflicts of Interest: The author declares no conflict of interest.

\section{References}

1. Hoogeboom-Pot, K.M.; Hernandez-Charpak, J.N.; Gu, X.; Frazer, T.D.; Anderson, E.H.; Chao, W.; Falcone, R.W.; Yang, R.; Murnane, M.M.; Kapteyn, H.C.; et al. A new regime of nanoscale thermal transport: Collective diffusion increases dissipation efficiency. Proc. Natl. Acad. Sci. USA 2015, 112, 4846-4851. [CrossRef] [PubMed]

2. Seo, D.; Neely, R.M.; Shen, K.; Singhal, U.; Alon, E.; Rabaey, J.M.; Carmena, J.M.; Maharbiz, M.M. Wireless recording in the peripheral nervous system with ultrasonic neural dust. Neuron 2016, 91, 529-539. [CrossRef] [PubMed]

3. Gross, E.; Shu, X.-Z.; Alayoglu, S.; Bechtel, H.A.; Martin, M.C.; Toste, F.D.; Somorjai, G.A. In Situ IR and X-ray High SpatialResolution Microspectroscopy Measurements of Multistep Organic Transformation in Flow Microreactor Catalyzed by Au Nanoclusters. J. Am. Chem. Soc. 2014, 136, 3624-3629. [CrossRef] [PubMed]

4. Heiland, J.J.; Warias, R.; Lotter, C.; Mauritz, L.; Fuchs, P.J.W.; Ohla, S.; Zeitler, K.; Belder, D. On-chip integration of organic synthesis and HPLC/MS analysis for monitoring stereoselective transformations at the micro-scale. Lab Chip 2017, $17,76-81$. [CrossRef] [PubMed]

5. Ahmed, M.U.; Hasan, Q.; Hossain, M.M.; Saito, M.; Tamiya, E. Meat species identification based on the loop mediated isothermal amplification and electrochemical DNA sensor. Food Control 2010, 21, 599-605. [CrossRef]

6. Zhang, X.; Chen, C.; Wu, J.; Ju, H. Bubble-Propelled Jellyfish-like Micromotors for DNA Sensing. ACS Appl. Mater. Interfaces 2019, 11, 13581-13588. [CrossRef] [PubMed]

7. Wang, J.; Dong, R.; Wu, H.; Cai, Y.; Ren, B. A Review on Artificial Micro/Nanomotors for Cancer-Targeted Delivery, Diagnosis, and Therapy. Nano-Micro Lett. 2020, 12, 11. [CrossRef]

8. Saito, M.; Kitamura, A.; Murahashi, M.; Yamanaka, K.; Hoa, L.Q.; Yamaguchi, Y.; Tamiya, E. Novel Gold-Capped Nanopillars Imprinted on a Polymer Film for Highly Sensitive Plasmonic Biosensing. Anal. Chem. 2012, 84, 5494-5500. [CrossRef] [PubMed]

9. Watanabe, T.; Yokoyama, Y.; Hayakawa, T. Structurally isolated photoactuation of graphene-mixed temperature-responsive hydrogels in soft-rigid series structure. Robomech J. 2019, 6, 11. [CrossRef] 